Article

\title{
$P$. gingivalis Lipopolysaccharide Stimulates the Upregulated Expression of the Pancreatic Cancer-Related Genes Regenerating Islet-Derived 3 A/G in Mouse Pancreas
}

\author{
Daichi Hiraki ${ }^{1}$, Osamu Uehara ${ }^{2}{ }^{1}$, Yasuhiro Kuramitsu ${ }^{3}$, Tetsuro Morikawa ${ }^{4}$, \\ Fumiya Harada ${ }^{5}$ (D), Koki Yoshida ${ }^{4}$ (D), Kozo Akino ${ }^{3}$, Itsuo Chiba ${ }^{2}$, Masahiro Asaka ${ }^{3}$ and \\ Yoshihiro Abiko ${ }^{4} *$
}

1 Division of Reconstructive Surgery for Oral and Maxillofacial Region, Department of Human Biology and Pathophysiology, School of Dentistry, Health Sciences University of Hokkaido, 1757 Kanazawa, Ishikari-Tobetsu, Hokkaido 061-0293, Japan; daichi0530@hoku-iryo-u.ac.jp

2 Division of Disease Control and Molecular Epidemiology, Department of Oral Growth and Development, School of Dentistry, Health Sciences University of Hokkaido, 1757 Kanazawa, Ishikari-Tobetsu, Hokkaido 061-0293, Japan; osamu@hoku-iryo-u.ac.jp (O.U.); i-chiba@hoku-iryo-u.ac.jp (I.C.)

3 Research Institute of Cancer Prevention, Health Sciences University of Hokkaido, 1757 Kanazawa, Ishikari-Tobetsu, Hokkaido 061-0293, Japan; climates@hoku-iryo-u.ac.jp (Y.K.); kozo_akino@komei.jp (K.A.); maasaka@hoku-iryo-u.ac.jp (M.A.)

4 Division of Oral Medicine and Pathology, Department of Human Biology and Pathophysiology, School of Dentistry, Health Sciences University of Hokkaido, 1757 Kanazawa, Ishikari-Tobetsu, Hokkaido 061-0293, Japan; t-morikawa@hoku-iryo-u.ac.jp (T.M.); denty@hoku-iryo-u.ac.jp (K.Y.)

5 Division of Oral and Maxillofacial Surgery, Department of Human Biology and Pathophysiology, School of Dentistry, Health Sciences University of Hokkaido, 1757 Kanazawa, Ishikari-Tobetsu, Hokkaido 061-0293, Japan; f-harada93@hoku-iryo-u.ac.jp

* Correspondence: yoshi-ab@hoku-iryo-u.ac.jp; Tel.: +81-133-23-1211

Received: 4 September 2020; Accepted: 1 October 2020; Published: 5 October 2020

check for updates

\begin{abstract}
Although epidemiological studies have shown a relationship between periodontal disease and pancreatic cancer, the molecular mechanisms involved remain unclear. In this study, the effects of systemic administration of Porphyromonas gingivalis lipopolysaccharide (PG-LPS) on gene expression were comprehensively explored in mouse pancreas that did not demonstrate any signs of inflammation. PG-LPS was prepared in physiological saline and intraperitoneally administered to male mice at a concentration of $5 \mathrm{mg} / \mathrm{kg}$ every 3 days for 1 month. After extracting total RNA from the excised mice pancreas, a comprehensive DNA microarray analysis of gene expression was performed. Tissue specimens were also subjected to hematoxylin-eosin staining and immunohistochemistry using anti-regenerating islet-derived $3 \mathrm{~A}$ and $\mathrm{G}(\operatorname{Reg} 3 A / G)$ antibody. ImageJ software was used to quantify the area of $\operatorname{Reg} 3 A / G$ positive cells in pancreatic islets by binarizing image date followed by area extraction. The results were compared using Mann-Whitney $U$ test. Data are presented as mean \pm standard deviation (SD) with $p<0.05$ considered as significant. Reg3G, a gene related to pancreatic cancer, was one of the 10 genes with the highest levels of expression in the pancreas stimulated with PG-LPS. The comprehensive analysis revealed a 73-fold increase in Reg3G expression level in the PG-LPS group when compared with the control group; in addition, the expression level of $\operatorname{Reg} 3 A$ was increased by 11-fold in the PG-LPS group. Image analysis showed that the ratio of $\operatorname{Reg} 3 A / G$ positive cells was higher in the PG-LPS group than the control. Immunostaining showed the presence of $\operatorname{Reg} 3 A / G$-positive cells in the alpha-cell equivalent areas around the islets of Langerhans in the PG-LPS group. These results support the notion that periodontal disease may be a risk factor for pancreatic cancer.
\end{abstract}


Keywords: P. gingivalis; lipopolysaccharide; pancreatic cancer; Reg3G

\section{Introduction}

Growing evidence suggests that periodontal disease may be a risk factor for various systemic conditions, such as diabetes, respiratory disease, infectious endocarditis, autoimmune diseases, and chronic kidney disease [1-4]. Bacteria, inflammatory cytokines, and other inflammation-related components are released into the systemic blood circulation, thus contributing to other systemic diseases. A recent large-scale cohort study found that anti-Porphyromonas gingivalis (P. gingivalis) antibody titers were higher in pancreatic cancer patients than in healthy subjects, thereby suggesting that periodontal disease might be involved in pancreatic cancer [5]. However, the molecular mechanisms in periodontal disease that may be related to pancreatic cancer have not been identified so far. The 5-year survival rate of pancreatic cancer is one of the lowest among all cancers, and it is the fourth leading cause of cancer deaths in Japan. Chronic pancreatitis and environmental factors such as alcohol consumption and obesity have been identified as potential risk factors for pancreatic cancer [6].

Cerulein has been used to experimentally induce both acute and chronic pancreatitis in mice [7]. In another study, a mouse model of severe acute pancreatitis was developed by inducing with lipopolysaccharides (LPS) derived from Escherichia coli (E. coli) [8]. These LPS are mainly recognized by toll-like receptor 4 (TLR4), which recognizes Gram-negative bacteria. On the other hand, the Gram-negative periodontal pathogen P. gingivalis is recognized by both TLR2 and TLR4 [9,10], which were found to be frequently overexpressed in pancreatic ductal carcinoma [11]. These findings may elucidate the mechanism of action of periodontal disease in the development of pancreatic cancer; however, the manner by which the onset of pancreatic cancer is independently affected by periodontal disease remains unknown. LPS are often used for acute responses in experimental models of acute pancreatitis [8]. Nevertheless, periodontal disease is a chronic inflammatory event and may not cause acute inflammatory changes in the pancreas. We previously developed a mouse model that is unaffected by acute inflammation with $P$. gingivalis lipopolysaccharide (PG-LPS) to observe the effect of LPS on the kidney [12]. The present study aimed to comprehensively explore the effects of systemic administration of PG-LPS on gene expression in the pancreas of these mice.

\section{Results}

\subsection{Microarray}

DNA microarray revealed 1029 probes with more than 2-fold expression and 326 probes with less than 0.5-fold expression following PG-LPS stimulation. The 10 genes with the highest fold change are listed in Table 1. Among them, Reg3G has been reported to be related to pancreatic cancer (Table 1) [13].

Table 1. Upregulated genes in the P. gingivalis lipopolysaccharide-administered vs. control animals.

\begin{tabular}{ccc}
\hline Gene Symbol & Protein Name & $\begin{array}{c}\text { Fold Change } \\
\text { (Control vs LPS) }\end{array}$ \\
\hline Ighg3 & Immunoglobulin heavy constant gamma 3 & 4123.958 \\
S100A8 & S100 calcium-binding protein A8 & 523.053 \\
S100A9 & S100 calcium-binding protein A9 & 336.474 \\
LOC102642252 & Immunoglobulin heavy chain variable region & 263.940 \\
Igk & Immunoglobulin kappa chain & 241.758 \\
Iglv1 & Immunoglobulin lambda variable 1 & 112.254 \\
Reg3G & Regenerating islet-derived 3 gamma & 73.305 \\
Igkv4-53 & Immunoglobulin kappa variable 4-53 & 66.337 \\
Ighv10-3 & Immunoglobulin heavy variable V10-3 & 51.897 \\
Chil3/Chil4 & Chitinase-like 3/Chitinase-like 4 & 48.847 \\
\hline
\end{tabular}




\subsection{Gene Expression}

The expression levels of $\operatorname{Reg} 3 A$ and $G$ were significantly higher in the pancreas of mice administered with LPS when compared to those in the controls (Figure $1 \mathrm{~A}, \mathrm{~B} ;{ }^{*} p<0.05$ ).
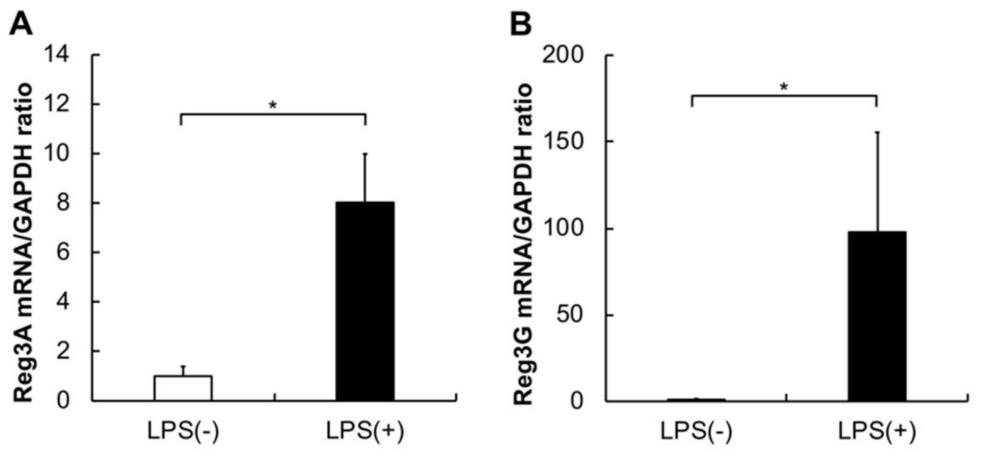

Figure 1. Expression profiles of Reg3A and G mRNAs in the P. gingivalis lipopolysaccharide (PG-LPS) and control mice. $\operatorname{Reg} 3 A$ and $G$ expression levels were measured by quantitative real-time polymerase chain reaction (qPCR). The expression levels were significantly higher in the PG-LPS mice than in the controls. Data are shown as mean \pm standard deviation (SD) obtained from three identical samples, Mann-Whitney $U$ test $\left({ }^{*} p<0.05 ; n=5\right.$ ). (A) Reg3A expression levels. (B) Reg3G expression levels.

\subsection{Histology, Immunohistochemistry, and Morphological Analysis}

No significant inflammatory changes were observed in the control group or PG-LPS group (Figure 2A,B). Strongly positive staining for Reg3G was observed in the islets of Langerhans in the LPS-administered mice (Figure 3A,B). Image analysis showed that the ratio of Reg3A and G-positive cells was significantly higher in the PG-LPS group than the control (Figure $4 ;{ }^{*} p<0.05$ ). Immunohistochemical staining showed $\operatorname{Reg} 3 A$ and G-positive cells in the alpha-cell equivalent areas around the islets of Langerhans in the PG-LPS group (Figure 5A-D).

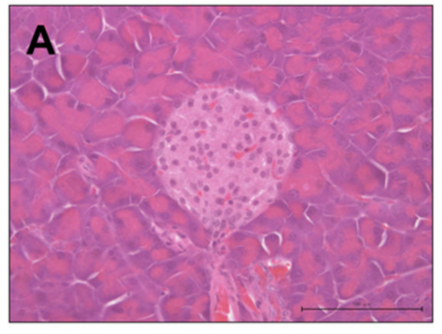

LPS (-)

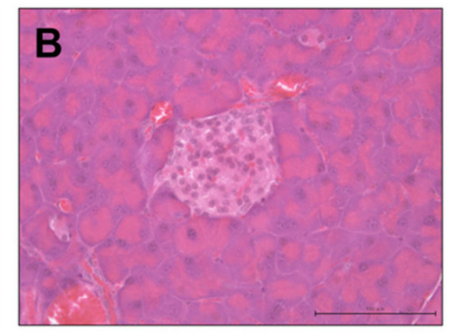

LPS (+)

Figure 2. H \& E staining of tissues from the P. gingivalis lipopolysaccharide (PG-LPS) and control mice. No significant acute inflammatory changes were observed between the control and PG-LPS mice. Scale bar, $100 \mu \mathrm{m}$. (A) PG-LPS(-). (B) PG-LPS(+).

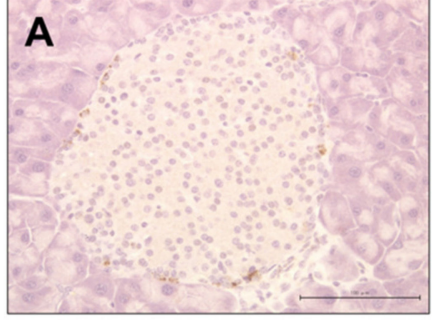

LPS (-)

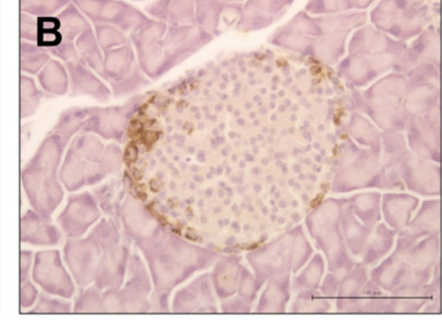

LPS (+)

Figure 3. Immunohistological staining for Reg3A/G in the P. gingivalis lipopolysaccharide (PG-LPS) and control mice. Strongly positive staining for $\operatorname{Reg} 3 A / G$ was observed in the islets of Langerhans in the LPS-administered mice. Scale bar, $100 \mu \mathrm{m}$. (A) PG-LPS(-). (B) PG-LPS(+). 


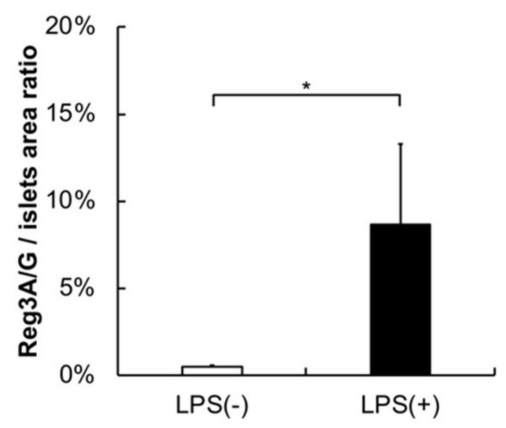

Figure 4. $\operatorname{Reg} 3 A / G /$ Islets area ratio from image analysis. Image analysis showed that the ratio of Reg3A/G-positive cells was significantly higher in the PG-LPS group than the control. Data are shown as mean \pm standard deviation (SD), Mann-Whitney $U$ test $(* p<0.05 ; n=5)$.

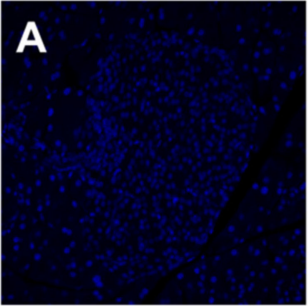

DAPI

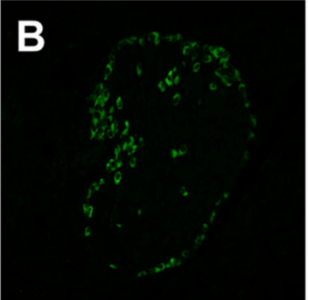

$\operatorname{Reg} 3 G$

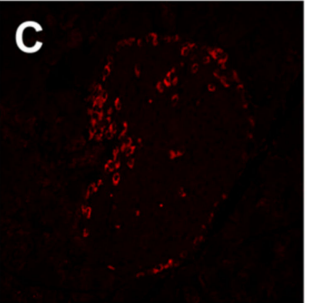

Glucagon

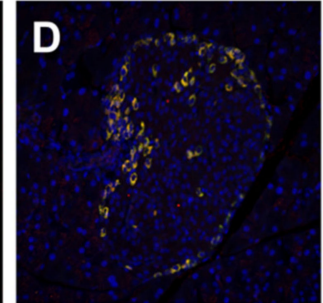

Merge

Figure 5. Immunochemical staining for Reg3A/G and alpha-cell in the P. gingivalis lipopolysaccharide (PG-LPS) mice. Immunofluorescence staining showed the presence of Reg3A/G-positive cells in the alpha-cell equivalent areas around the islets of Langerhans in the PG-LPS group. (A) 4',6-diamidino-2-phenylindole (DAPI). (B) Reg3A/G. (C) Glucagon. (D) Merge.

\section{Discussion}

In the present study, we observed the effect of PG-LPS on the pancreas in an attempt to establish a mouse model that is not affected by acute inflammation in various organs; the gene expression of the pancreas was exhaustively analyzed in this model. Based on the results of the microarray analysis, Ighg3, S100A8, S100A9, LOC102642252, Igk, Iglv1, Reg3G, Igkv4-53, Ighv10-3, and Chil3/Chil4 were the top 10 genes with the highest expression levels (above 45-fold change) in the pancreas of mice stimulated with PG-LPS (Table 1). Reg3A and $G$ have been involved in the development and progression of pancreatic cancer [14]. Reg3A demonstrated a 11.256-fold change in the microarray data, and the upregulation was confirmed by qRT-PCR in the current study. The upregulated expression levels of Reg3A and G might play a key role in PG-LPS-related pancreatic cancer in mouse.

The regenerating (Reg) protein family comprises C-type lectin-like proteins that are initially discovered in the pancreas and are expressed in multiple organs [15]. Reg family proteins including $\operatorname{Reg} 1 A, 1 B, 3 A, 3 G$, and 4 act as anti-inflammatory, antiapoptotic, and mitogenic agents in multiple physiological and disease conditions [16]. The Reg3 proteins have promoted pancreatic islet growth in response to inflammation and injury [17]. In addition, Reg3 may be involved in the progression of precancerous lesions and cancer in the pancreas [18]. The expression of Reg3A was significantly upregulated in pancreatic, liver, and colorectal cancer in humans [19-21], while significant upregulation of Reg3G has been specifically noted in pancreatic cancer [13]. The Reg3A and $G$ proteins share $85 \%$ sequence homology [22] and are often collectively expressed as Reg3A/G. The expression levels of Reg3A and $B$ may be overlapped. The upregulated expression levels of Reg $3 A / G$ stimulated with PG-LPS in the present study imply that these proteins may be key for periodontal disease-related pancreatic cancer in human. A recent study showed that Reg3A/G were highly expressed in pancreatic acinar-ductal metaplasia, but not in healthy or cancerous pancreas; Reg $3 A$ protein was found to promote pancreatic duct metaplasia in a 3D culture of mouse acinar cells [17]. Reg3G has been reported to function as an immunosuppressive promoter by suppressing the antitumor effects of $\mathrm{T}$ cells in a murine 
model of pancreatic cancer [13]. These findings indicate that $R e g 3 A / G$ may be indirectly involved in carcinogenesis by inducing the development of precancerous lesions or via immunosuppression.

Immunohistochemical staining revealed co-localization of Reg3A/G- and glucagon-positive cells around the pancreatic islets in the PG-LPS group. In a previous study, $\operatorname{Reg} 3 A$ was found to be co-localized with alpha cells in islets of Langerhans in mice [23]. In addition, mRNA expression levels of $\operatorname{Reg} 3 A$ were upregulated by stimulation with inflammatory cytokines, such as IL-6 [24]; Reg3G was not detected in islets but was detected in the total pancreas [24]. Immunohistochemical co-localization with glucagon-positive cells may be mainly affected by Reg3A expression. Reg3G has been identified as a pancreatitis-associated protein released by the acini during acute pancreatitis and injury [25]. In the current study, no obvious inflammatory infiltration or injury was noted in the pancreas, and no immunohistochemical expression of Reg3A/G was observed in the acini. The upregulated expression of Reg3G may not be related to inflammatory damage; nonetheless, it might be of importance in the PG-LPS-related pancreatic response.

The mechanism by which PG-LPS induces the upregulation of both Reg3A and $G$ remains unknown. PG-LPS is recognized by TLR2 and 4 [10], whereas LPS derived from E. coli is recognized by TLR2 [9]. TLR2 and 4 are found in a diversity of cells of the immune system. Both receptors have been localized in endocrine and exocrine tissues in the pancreas [26]. Several inflammatory cytokines are activated by TLR2 and 4 via NF-kB and MAPK pathways in the cells [27]. Recently, the P. gingivalis membrane, which is supposed to contain LPS, was reported to activate both NF-kB and MAPK [28]. LPS derived from E. coli induces the upregulated expression of Reg3G via the p38 MAPK pathway [29]. These pathways may be involved in the upregulation of $\operatorname{Reg} 3 A$ and $G$ by PG-LPS stimulation. Further investigations are needed to clarify this phenomenon.

Although periodontal diseases have been shown as a risk factor of pancreatic cancer, their effect on the pancreas remains unclear. In the present study, we firstly detected a key molecule, the $\operatorname{Reg} 3 A / G$, which might be involved in this phenomenon and could be a target for the prevention of periodontal-related pancreatic cancer. Recently, Reg3G was detected in urine obtained from experimentally induced chronic pancreatitis [30]. The early detection of $\operatorname{Reg} 3 A / G$ in urine or blood may prove useful for the prevention of cancer in patients with periodontal diseases. Our data are expected to be applied in a clinical setting.

\section{Materials and Methods}

\subsection{Animals}

All procedures involving animals were performed according to the Regulations for the Care and Use of Laboratory Animals at the Health Sciences University of Hokkaido. This experimental protocol was approved by the animal experimental committee and ethics committee of the Health Sciences University of Hokkaido (Permission number: 089, 22/06/2018). PG-LPS (lipopolysaccharide from P. gingivalis ATCC 33277; Wako, Osaka, Japan) was prepared in physiological saline and intraperitoneally administered to C57BL/J mice (age 6-8 weeks; Sankyo Labo Service Corporation, Sapporo, Japan) at a dosage of $5 \mathrm{mg} / \mathrm{kg}$ every 3 days $(84 \mathrm{~h}$ ) for a period of 1 month (10 doses). Additionally, a control group was administered with the same volume of physiological saline without PG-LPS using the same schedule. Both groups were fed at standard laboratory chow and allowed free access to water in an air-conditioned room ( $n=5$ in each group). Anesthesia was carefully induced by intraperitoneal injection of pentobarbital (Somnopentyl ${ }^{\circledR}$, Kyoritsu Seiyaku Co., Tokyo, Japan; 100 mg/kg body weight).

\subsection{RNA Extraction and Microarray}

Three days after the last injection, the mice were sacrificed by cervical dislocation under deep anesthesia, and the pancreases were extracted. Total RNA was extracted from the pancreas using RNeasy ${ }^{\circledR}$ Mini kit (Qiagen $\mathrm{GmbH}$, Hilden, Germany) according to the manufacturer's instructions, 
and microarray was performed with SurePrint G3 Rat GE 8x60K Ver.2.0 (Agilent Technologies, Ltd., Santa Clara, CA, USA).

\subsection{Quantitative Reverse Transcriptase-Polymerase Chain Reaction (RT-PCR)}

The genes which showed the highest level of expression in microarray analysis were further confirmed by real-time RT-PCR. Reverse transcription of the extracted RNA was done using ReverTra Ace ${ }^{\circledR}$ qPCR RT Master Mix (Toyobo, Osaka, Japan). Quantitative real-time PCR was performed to demonstrate the expression level of mRNA using LightCycler ${ }^{\circledR}$ Nano (Roche Diagnostics, Basel, Switzerland). The reaction mix for PCR consisted of cDNA, a pair of primer and KAPA SYBR FAST qPCR Mix (Nippon Genetics Co. Lid., Tokyo, Japan). PCR was performed under the following conditions: initial incubation at $50{ }^{\circ} \mathrm{C}$ for $2 \mathrm{~min}$, denaturation at $95{ }^{\circ} \mathrm{C}$ for $10 \mathrm{~min}, 40$ cycles of denaturation at $95^{\circ} \mathrm{C}$ for $15 \mathrm{~s}$, and annulation at $60^{\circ} \mathrm{C}$ for $1 \mathrm{~min}$. The relative mRNA expression level was calculated as the $\mathrm{Cq}$ obtained after subtracting the $\mathrm{Cq}$ value of GAPDH from the $\mathrm{Cq}$ value of the target gene using the $\Delta \Delta \mathrm{Cq}$ method [31]. The primer sequences used in this study are shown in Table 2 .

Table 2. Real-time polymerase chain reaction (PCR) primer sequences used in this study.

\begin{tabular}{ccc}
\hline Gene & Forward & Reverse \\
\hline GAPDH & AGAACATCATCCCTGCATCC & CACATTGGGGGTAGGAACAC \\
$\operatorname{Reg} 3 A$ & TTCCTTTGTGTCCTCCTTGG & ACCTCCATTGGGTTGTTGAC \\
$\operatorname{Reg} 3 G$ & AACAGAGGTGGATGGGAGTG & GTGATTGCCTGAGGAAGAGG \\
\hline
\end{tabular}

\subsection{Histological, Immunohistochemical, Immunofluorescence, and Morphological Analyses}

The pancreas obtained from the mouse was fixed in $10 \%$ neutral buffered formalin for $24 \mathrm{~h}$. It was then embedded in paraffin and coronal sections of $5 \mu \mathrm{m}$ thickness were made. The sections were stained with hematoxylin-eosin ( $\mathrm{H} \& \mathrm{E})$ for morphological analysis. Images of the stained sections were taken using OLYMPUS BX50 (Olympus, Tokyo, Japan) using FLOVEL Filing System camera (Flovel, Tokyo, Japan).

For immunohistochemistry, sections were deparaffinized in xylene and rehydrated in ethanol. The peroxidase activity was removed with $3 \% \mathrm{H}_{2} \mathrm{O}_{2} /$ methanol for $10 \mathrm{~min}$ at room temperature (RT) which was then blocked with $3 \%$ bovine serum albumin. The sections were incubated for $60 \mathrm{~min}$ at $37^{\circ} \mathrm{C}$ after the addition of primary anti-Reg3G antibody (ab198216; Abcam, Cambridge, UK; dilution, 1:200). The sections were then washed with PBS and incubated for $30 \mathrm{~min}$ at $37^{\circ} \mathrm{C}$ after addition of secondary antibody EnVision + System-horseradish peroxidase (HRP)-labeled polymer goat anti-rabbit IgG (K4002; Dako North America, Inc., CA, USA) or EnVision + System-HRP-labeled polymer goat anti-mouse IgG (K4000; Dako North America, Inc.). DAB Peroxidase (HRP) Substrate Kit (DAKO Japan, Tokyo, Japan) was used to visualize the staining which produced brown color. Counterstaining with hematoxylin was done to stain the cell nuclei. Images were taken using OLYMPUS BX50 (Olympus, Tokyo, Japan) using a FLOVEL Filing System camera (Flovel, Tokyo, Japan). Binary image thresholding is the most commonly used technique to quantitatively examine changes in immunolabeled material [32]. We used ImageJ software (National Institutes of Health, Bethesda, MD, USA) to quantify the area of Reg $3 A$ and $G$-positive cells in pancreatic islets by binarizing image date followed by area extraction.

For immunofluorescence, the sections were first blocked with 3\% normal goat serum for $30 \mathrm{~min}$. The sections were incubated with primary anti-Reg3G antibody (ab198216; Abcam, Cambridge, UK; dilution, 1:100) and primary anti-Glucagon antibody (ab36232; Abcam, Cambridge, UK; dilution, 1:100) for $60 \mathrm{~min}$ at RT. Secondary antibody, Goat anti-rabbit $\operatorname{IgG}(\mathrm{H}+\mathrm{L})$ (AF488, Thermo Fisher Scientific, Tokyo, Japan; dilution, 1:100) or Donkey Anti-Sheep IgG (H+L) (CF543, Biotium, CA, USA; dilution, 1:100) according to the species of primary antibodies were then added and incubated for $30 \mathrm{~min}$ at RT. DAPI (SouthernBiotech, AL, USA) was used to stain the cell nuclei. Sections were visualized with a confocal microscope (C1siReady, NIKON, Tokyo, Japan). 


\subsection{Statistical Analysis}

Statistical analysis was performed using SPSS version 23 software (SPSS, Inc., Chicago, IL, USA). The results were compared using Mann-Whitney $U$ test. Data are presented as mean \pm standard deviation (SD) with $p<0.05$ considered as significant.

Author Contributions: Conceptualization, D.H., O.U., and Y.A.; methodology, D.H., O.U., Y.K., T.M., F.H., K.Y., K.A., I.C., M.A., and Y.A.; software, D.H. and O.U.; validation, D.H. and O.U.; formal analysis, D.H. and O.U.; investigation, D.H., O.U., Y.K., T.M., F.H., K.Y., K.A., I.C., M.A., and Y.A.; resources, D.H., O.U., and Y.A.; data curation, D.H., O.U., Y.K., T.M., F.H., and Y.A.; writing-original draft preparation, D.H. and O.U.; writing-review and editing, D.H., O.U., Y.K., and Y.A.; visualization, D.H. and O.U.; supervision, D.H., O.U., Y.K., and Y.A.; project administration, D.H., O.U., Y.K., and Y.A.; funding acquisition, O.U., Y.K., M.A., and Y.A. All authors have read and agreed to the published version of the manuscript.

Funding: This research was supported by the Health Labour Sciences Research Grant, the Grant-in-Aid for Young Scientists (B) from the Ministry of Education, Science, Sports, and Culture of Japan (No. 15K20647), Health Labour Sciences Research Grant (No. 201706022A), and the Grant-in-Aid for the 2019-2020 Research Project of the Research Institute of Health Sciences, Health Sciences University of Hokkaido.

Conflicts of Interest: The authors declare no conflict of interest.

\section{Abbreviations}

$\begin{array}{ll}\text { Chil3/Chil4 } & \text { Chitinase-like 3/Chitinase-like 4 } \\ \text { E. coli } & \text { Escherichia coli } \\ \text { H \& E } & \text { Hematoxylin-eosin } \\ \text { HRP } & \text { Horseradish peroxidase } \\ \text { Ighg3 } & \text { Immunoglobulin heavy constant gamma 3 } \\ \text { Ighv10-3 } & \text { Immunoglobulin heavy variable V10-3 } \\ \text { Igk } & \text { Immunoglobulin kappa chain } \\ \text { Igkv4-53 } & \text { Immunoglobulin kappa variable 4-53 } \\ \text { Iglv1 } & \text { Immunoglobulin lambda variable 1 } \\ \text { LPS } & \text { Lipopolysaccharides } \\ \text { P. gingivalis } & \text { Porphyromonas gingivalis } \\ \text { PG-LPS } & \text { P. gingivalis lipopolysaccharide } \\ \text { RT-PCR } & \text { Quantitative reverse transcriptase-polymerase chain reaction } \\ \text { Reg } & \text { Regenerating } \\ \text { Reg3G } & \text { Regenerating islet-derived } 3 \text { gamma } \\ \text { S100A8 } & \text { S100 calcium binding protein A8 } \\ \text { S100A9 } & \text { S100 calcium binding protein A9 } \\ \text { SD } & \text { Standard deviation } \\ \text { TLR4 } & \text { Toll-like receptor 4 }\end{array}$

\section{References}

1. Llambés, F.; Arias-Herrera, S.; Caffesse, R. Relationship between diabetes and periodontal infection. World J. Diabetes 2015, 6, 927-935. [CrossRef] [PubMed]

2. Linden, G.J.; Lyons, A.; Scannapieco, F.A. Periodontal systemic associations: Review of the evidence. J. Periodontol. 2013, 40, 8-19. [CrossRef] [PubMed]

3. Chambrone, L.; Foz, A.M.; Guglielmetti, M.R.; Pannuti, C.M.; Artese, H.P.; Feres, M.; Romito, G.A. Periodontitis and chronic kidney disease: A systematic review of the association of diseases and the effect of periodontal treatment on estimated glomerular filtration rate. J. Clin. Periodontol. 2013, 40, 443-456. [CrossRef] [PubMed]

4. Ogrendik, M. Rheumatoid arthritis is an autoimmune disease caused by periodontal pathogens. Int. J. Gen. Med. 2013, 6, 383-386. [CrossRef]

5. Michaud, D.S.; Izard, J.; Wilhelm-Benartzi, C.S.; You, D.H.; Grote, V.A.; Tjønneland, A.; Dahm, C.C.; Overvad, K.; Jenab, M.; Fedirko, V.; et al. Plasma antibodies to oral bacteria and risk of pancreatic cancer in a large European prospective cohort study. Gut 2013, 62, 1764-1770. [CrossRef] 
6. Yadav, D.; Lowenfels, A.B. The epidemiology of pancreatitis and pancreatic cancer. Gastroenterology 2013, 144, 1252-1261. [CrossRef]

7. Terao, K.; Wake, H.; Adachi, N.; Liu, K.; Teshigawara, K.; Takahashi, H.; Mori, S.; Nishibori, M. Histidine-Rich Glycoprotein Suppresses Hyperinflammatory Responses of Lung in a Severe Acute Pancreatitis Mouse Model. Pancreas 2018, 47, 1156-1164. [CrossRef]

8. Ding, S.P.; Li, J.C.; Jin, C. A mouse model of severe acute pancreatitis induced with caerulein and lipopolysaccharide. World J. Gastroenterol. 2003, 9, 584-589. [CrossRef]

9. Hoshino, K.; Takeuchi, O.; Kawai, T.; Sanjo, H.; Ogawa, T.; Takeda, Y.; Takeda, K.; Akira, S. Cutting edge: Toll-like receptor 4 (TLR4)-deficient mice are hyporesponsive to lipopolysaccharide: Evidence for TLR4 as the Lps gene product. J. Immunol. 1999, 162, 3749-3752.

10. Darveau, R.P.; Pham, T.T.T.; Lemley, K.; Reife, R.A.; Bainbridge, B.W.; Coats, S.R.; Howald, W.N.; Way, S.S.; Hajjar, A.M. Porphyromonas gingivalis lipopolysaccharide contains multiple lipid A species that functionally interact with both toll-like receptors 2 and 4. Infect. Immun. 2004, 72, 5041-5051. [CrossRef]

11. Lanki, M.A.; Seppänen, H.E.; Mustonen, H.K.; Böckelman, C.; Juuti, A.T.; Hagström, J.K.; Haglund, C.H. Toll-like receptor 2 and Toll-like receptor 4 predict favorable prognosis in local pancreatic cancer. Tumor Biol. 2018, 40, 1-9. [CrossRef] [PubMed]

12. Harada, F.; Uehara, O.; Morikawa, T.; Hiraki, D.; Onishi, A.; Toraya, S.; Adhikari, B.R.; Takai, R.; Yoshida, K.; Sato, J.; et al. Effect of systemic administration of lipopolysaccharides derived from Porphyromonas gingivalis on gene expression in mice kidney. Med. Mol. Morphol. 2018, 51, 156-165. [CrossRef] [PubMed]

13. Liu, X.; Zhou, Z.; Cheng, Q.; Wang, H.; Cao, H.; Xu, Q.; Tuo, Y.; Jiang, L.; Zou, Y.; Ren, H.; et al. Acceleration of pancreatic tumorigenesis under immunosuppressive microenvironment induced by Reg3g overexpression. Cell Death Dis. 2017, 8, 1-12. [CrossRef] [PubMed]

14. Yin, G.; Du, J.; Cao, H.; Liu, X.; Xu, Q. Reg3g Promotes Pancreatic Carcinogenesis in a Murine Model of Chronic Pancreatitis. Dig. Dis. Sci. 2015, 60, 3656-3668. [CrossRef] [PubMed]

15. Hartupee, J.C.; Zhang, H.; Bonaldo, M.F.; Soares, M.B.; Dieckgraefe, B.K. Isolation and characterization of a cDNA encoding a novel member of the human regenerating protein family: Reg IV. Biochim. Biophys. Acta Gene Struct. Expr. 2001, 1518, 287-293. [CrossRef]

16. Parikh, A.; Stephan, A.-F.; Tzanakakis, E.S. Regeneratin proteins and their expression, regulation and signalling. Biomol. Concepts 2012, 3, 57-70. [CrossRef]

17. Li, Q.; Wang, H.; Zogopoulos, G.; Shao, Q.; Dong, K.; Lv, F.; Nwilati, K.; Gui, X.Y.; Cuggia, A.; Liu, J.L.; et al. Reg proteins promote acinar-to-ductal metaplasia and act as novel diagnostic and prognostic markers in pancreatic ductal adenocarcinoma. Oncotarget 2016, 7, 77838-77853. [CrossRef]

18. Gironella, M.; Calvo, C.; Fernández, A.; Closa, D.; Iovanna, J.L.; Rosello-Catafau, J.; Folch-Puy, E. Reg3b deficiency impairs pancreatic tumor growth by skewing macrophage polarization. Cancer Res. 2013, 73, 5682-5694. [CrossRef]

19. Porterfield, M.; Zhao, P.; Han, H.; Cunningham, J.; Aoki, K.; von Hoff, D.D.; Demeure, M.J.; Pierce, J.M.; Tiemeyer, M.; Wells, L. Discrimination between adenocarcinoma and normal pancreatic ductal fluid by proteomic and glycomic analysis. J. Proteome Res. 2014, 13, 395-407. [CrossRef]

20. Cavard, C.; Terris, B.; Grimber, G.; Christa, L.; Audard, V.; Radenen-Bussiere, B.; Simon, M.T.; Renard, C.A.; Buendia, M.A.; Perret, C. Overexpression of regenerating islet-derived 1 alpha and 3 alpha genes in human primary liver tumors with $\beta$-catenin mutations. Oncogene 2006, 25, 599-608. [CrossRef]

21. Ye, Y.; Xiao, L.; Wang, S.-J.; Yue, W.; Yin, Q.-S.; Sun, M.-Y.; Xia, W.; Shao, Z.-Y.; Zhang, H. Up-regulation of REG3A in colorectal cancer cells confers proliferation and correlates with colorectal cancer risk. Oncotarget 2015, 7, 3921-3933. [CrossRef] [PubMed]

22. Nata, K.; Liu, Y.; Xu, L.; Ikeda, T.; Akiyama, T.; Noguchi, N.; Kawaguchi, S.; Yamauchi, A.; Takahashi, I.; Shervani, N.J.; et al. Molecular cloning, expression and chromosomal localization of a novel human REG family gene, REG III. Gene 2004, 340, 161-170. [CrossRef] [PubMed]

23. Taylor-Fishwick, D.A.; Bowman, A.; Korngiebel-Rosique, M.C.; Vinik, A.I. Pancreatic islet immunoreactivity to the Reg protein INGAP. J. Histochem. Cytochem. 2008, 56, 183-191. [CrossRef]

24. Gurr, W.; Yavari, R.; Wen, L.; Shaw, M.; Mora, C.; Christa, L.; Sherwin, R.S. A Reg family protein is overexpressed in islets from a patient with new-onset type 1 diabetes and acts as T-cell autoantigen in NOD mice. Diabetes 2002, 51, 339-346. [CrossRef] [PubMed] 
25. Norkina, O.; Graf, R.; Appenzeller, P.; de Lisle, R.C. Caerulein-induced acute pancreatitis in mice that constitutively overexpress Reg/PAP genes. BMC Gastroenterol. 2006, 6, 1-11. [CrossRef] [PubMed]

26. Vaz, J.; Akbarshahi, H.; Andersson, R. Controversial role of toll-like receptors in acute pancreatitis. World J. Gastroenterol. 2013, 19, 616-630. [CrossRef] [PubMed]

27. Zhang, G.; Ghosh, S. Toll-like receptor-mediated NF-kB activation: A phylogenetically conserved paradigm in innate immunity. J. Clin. Invest. 2001, 107, 13-19. [CrossRef]

28. Groeger, S.; Jarzina, F.; Domann, E.; Meyle, J. Porphyromonas gingivalis activates NFKB and MAPK pathways in human oral epithelial cells. BMC Immunol. 2017, 18, 1-11. [CrossRef]

29. Säkkinen, H.; Aro, J.; Kaikkonen, L.; Ohukainen, P.; Näpänkangas, J.; Tokola, H.; Ruskoaho, H.; Rysä, J. Mitogen-activated protein kinase p38 target regenerating islet-derived $3 \gamma$ expression is upregulated in cardiac inflammatory response in the rat heart. Physiol. Rep. 2016, 4, e12996. [CrossRef]

30. Zhang, L.; Li, Y.; Gao, Y. Early changes in the urine proteome in a diethyldithiocarbamate-induced chronic pancreatitis rat model. J. Proteom. 2018, 186, 8-14. [CrossRef]

31. Livak, K.J.; Schmittgen, T.D. Analysis of relative gene expression data using real-time quantitative PCR and the 2- $\Delta \Delta \mathrm{CT}$ method. Methods 2001, 25, 402-408. [CrossRef] [PubMed]

32. Johnson, S.J.; Walker, F.R. Strategies to improve quantitative assessment of immunohistochemical and immunofluorescent labelling. Sci. Rep. 2015, 5, 1-4. [CrossRef] [PubMed]

(C) 2020 by the authors. Licensee MDPI, Basel, Switzerland. This article is an open access article distributed under the terms and conditions of the Creative Commons Attribution (CC BY) license (http://creativecommons.org/licenses/by/4.0/). 